\title{
Abdominal surgery in autoimmune and autoimmune-related diseases: A review
}

\author{
Erdal Uysal $^{1 *}$, Mehmet Dokur ${ }^{2}$, Gokturk Maralcan $^{1}$ \\ ${ }^{1}$ SANKO UNIVERSITY, FACULTY OF MEDICINE, DEPARTMENT OF GENERAL SURGERY, GAZIANTEP, TURKEY \\ ${ }^{2}$ BIRUNI UNIVERSITY, FACULTY OF MEDICINE, DEPARTMENT OF EMERGENCY MEDICINE, ISTANBUL, TURKEY
}

Autoimmune diseases can have a widespread effect throughout the system and can cause high mortality and morbidity, depending on their involvement in the abdominal organs and systems. Most of the abdominal organs are damaged as a result of the direct or/ and indirect effects of autoimmune diseases. Therefore, abdominal surgeries should be performed to eliminate any complications related to these effects. There could be a significant relationship between abdominal surgery and autoimmune and autoimmune-related diseases. The aim of this study was to reveal the possible relationship between autoimmune and autoimmune-related diseases that cause significant mortality and morbidity. In this way, we further aimed at increasing the awareness of clinicians on this subject, along with providing them with the related publications on autoimmune and autoimmune-related diseases and abdominal surgery. Taking all these into consideration, autoimmune and autoimmune-related diseases can also influence the abdominal organs. The influence may be directly related to the involvement of the organ and system as a result of the autoimmune disease or indirectly related to the influence of the organs and systems. Such influence leading to complications may require urgent or elective abdominal surgery, which can further cause high mortality and morbidity. Therefore, it is significant for all clinicians, especially surgeons, to be aware of the relationship between autoimmune diseases and abdominal surgery. The early detection and treatment of the complications related to the abdominal involvement of autoimmune and autoimmune-related diseases could decrease mortality and morbidity.
\end{abstract}

\section{Introduction}

Autoimmune diseases are considered clinical conditions, which are the result of the immune reactions occurring atypically in the organism. While its etiology is still not clearly known, in some cases, genetic, infectious or environmental factors are among the triggering factors. The prevalence of autoimmunity has been reported ranging from 3 to $5 \%$ in the general population, based on several epidemiological studies [1,2].

Although autoimmune diseases are not relatively common, their impact resulting in mortality and morbidity are vital [3,4]. Autoimmune diseases can have a widespread effect throughout the system and can cause high mortality and morbidity, depending on their involvement in the abdominal organs and systems [5]. Most of the abdominal organs are damaged as a result of the direct or/and indirect effects of autoimmune diseases.
Therefore, abdominal surgeries should be performed to eliminate any complications related to these effects. Gastrointestinal perforation, bleeding, mesenteric ischemia, intestinal necrosis, solid organ ruptures, intraabdominal bleeding and aortic dissection are among the examples of the high mortality clinical conditions requiring emergency abdominal surgeries [6-8]. In the existence of isolated organ involvement and medical treatment refractory disease, further elective abdominal surgical procedures (e.g. splenectomy, cholecystectomy, transplantation and aortic aneurysm repair) can be necessary [9-11]. All these indicate that there could be a significant relationship between abdominal surgery and autoimmune and autoimmune-related diseases. In our preliminary questionnaire, among the surgeons who usually perform abdominal surgery, the results suggested that surgeons have the highest awareness of the surgical indication and clinical approaches of inflammatory bowel 
diseases and autoimmune hematological diseases. Yet, they were not able to clearly indicate the exact relationship between many autoimmune and autoimmune-related diseases and abdominal surgery. For this reason, if the clinicians, especially surgeons, are aware of the subject, this could provide the opportunity for an early diagnosis and treatment of such complications caused by autoimmune and autoimmune-related diseases, thus reducing the mortality and morbidity rates.

To the best of our knowledge, there has not been any study published on the relationship between autoimmune and autoimmune-related diseases and abdominal surgery in a single study. Generally, in the literature, there are published studies revealing the relationship between a single autoimmune disease and abdominal surgery. Some of these studies include the case reports on rare diseases.

The aim of this study was to reveal the possible relationship between autoimmune and autoimmune-related diseases that cause significant mortality and morbidity rates. In this way, we further aimed at increasing the awareness of clinicians on this subject along with providing them with the related publications on autoimmune and autoimmune-related diseases and abdominal surgery.

\section{Discussion}

The data of this study were obtained through the search conducted on the Thomson Reuters Web of Science (WOS) (Clarivate Analytics, Philadelphia, Pennsylvania, United States) and PubMed (US National Library of MedicineNational Institutes of Health). WOS covers more than 8,500 notable and major journals encompassing 150 disciplines from the 1900s up to the present moment [12]. In addition to WOS, we conducted further search via PubMed database (U.S. National Library of Medicine), which is affiliated to the National Center for Biotechnology Information, since it covers the widely preferred top medical journals.

The data were initially searched as follows, we typed the term using the keyword "Autoimmune diseases abdominal surgery" into the search box of WOS and Pubmed basic research, along with the selection of all the years. There were no restrictions on the journals. Then, we further categorized the results using over 100 autoimmune and autoimmune-related disease names obtained through the U.S. National Library of Medicine, the U.S. National Institute of Allergy and Infectious Diseases, the American Autoimmune Related Diseases Association (AARDA) (https://www.aarda.org/diseaselist/). We typed each name of the disease into the search box of WOS and Pubmed basic research. Finally, the articles on the subject were evaluated separately, classified, and tabulated.

Since the abdominal involvement of autoimmune and autoimmune-related diseases can result in serious mortality and morbidity rates, urgent and elective abdominal surgical interventions are necessary to reduce mortality and morbidity [13]. In autoimmune diseases, through the direct involvement of the organs and the systems, the side effects of medical treatments cause complications that require abdominal surgery. In some cases, the organ involvement of autoimmune diseases mimics a tumor which leads to the need for abdominal surgery in diagnosis and treatment. Whist the digestive system is the mostly affected system in the abdomen, vascular structures, connective tissues and lymphoid organs are also among the commonly affected systems $[14,15]$. The most common complications include gastrointestinal perforation, bleeding, mesenteric ischemia, acute cholecystitis, ileus, intra-abdominal abscess and organ ruptures. Aortic aneurysm, aortic dissection and other visceral aneurysms are also the clinical conditions requiring abdominal surgery because of the vascular involvement.

The end-stage organ failure may occur due to the organ involvement of autoimmune disease whose treatment can be provided through organ transplantation. Autoimmune hepatitis, especially sclerotic cholangitis and primary biliary cirrhosis, are among the most common cholestatic diseases requiring liver transplantation [16]. Renal transplantation is considered as a decent choice in the treatment of end-stage renal disease associated with the complication of Systemic lupus erythematosus caused by lupus nephritis [17]. Intestinal transplantation could be required for the treatment of Churg-Strauss syndrome and Crohn's disease extensive bowel resection which lead to a short bowel syndrome [18].

Inflammatory bowel diseases are also included in the autoimmune disease group. Even though ulcerative colitis and Crohn's disease primarily involve the colon and the small intestine, they can further influence other systems through their extraintestinal involvement. Ulcerative colitis is an autoimmune disease which is characterized by T-cells infiltrating in the colon [19]. Total proctocolectomy with permenent ileostomy or proctocolectomy with ileal pouch-anal anastomosis formation, and diverting ileostomy can be treatment of choice in case of medically refractory ulcerative colitis [20]. Abdominal surgery may be required in case of complications due to ulcerative colitis such as toxic megacolon, colon perforation, intestinal hemorrhage, colon obstruction and colon-rectum fistulas (vaginal, bladder, cutaneous) [21,22]. There is a higher risk of colon cancer in patients with ulcerative colitis. Furthermore, this risk is more noticeable, especially in the patients with total or extensive colitis for more than 8-10 years [23]. Abdominal surgery could be essential for the patients with a precancerous lesion detected by colonoscopy and the patients diagnosed and confirmed with colon cancer [24]. Hepatobiliary and pancreatic manifestations (e.g. cholelithiasis, acute pancreatitis, the association with primary sclerotic cholangitis and the 
association with cholangiocarcinoma) can be seen in ulcerative colitis [25,26]. Abdominal surgery could be required to treat these manifestations.

Crohn's disease also causes clinical conditions similar to ulcerative colitis. Abdominal surgery is needed to provide the remission of the disease and to treat complications such as toxic megacolon, intestinal perforation, intestinal hemorrhage, intestinal obstruction and fistulas (vaginal, bladder, cutaneous, bowel) [27]. Moreover, surgical interventions might be required because of the increased risk of small bowel and colon cancer [28]. As it can be seen in ulcerative colitis, hepatobiliary and pancreatic manifestations such as the increased risk of gallstones, acute pancreatitis, the association with primary sclerotic cholangitis are observed [29]. Abdominal surgery may also be required in the treatment of such manifestations. Crohn's disease can recur in healthy small intestine following small bowel resection. Reconstructed small bowel resections due to obstructions, strictures and recurrences lead to short bowel syndromes in time. Therefore, intestinal transplantation may be needed in such cases [30].

Surgical acute abdomen can emerge because of the complications associated with autoimmune and autoimmune related diseases. But, a surgical intervention is not needed for in the acute abdomen encountered in Addison's disease, which can manifest through nonspecific symptoms of adrenal failure. However, acute abdominal signs may be observed in some patients suffering from Addison's disease due to rhabdomyolysis. The treatment with cortisone is the best option for these patients. Thus, acute adrenal failure should be always considered in patients with Addison's disease along with the acute abdominal findings, in order to prevent unnecessary surgery [31]. Autoimmune pancreatitis may mimic the peritonitis acute surgical abdomen caused by systemic lupus erythematosus [32]. Patients with acute abdominal findings who do not require surgery have also been reported in celiac disease. Thus, the improvement of symptoms can be achieved by choosing the medical treatment and thus avoiding unnecessary surgery [33].

Gastrointestinal perforations are among the most common complications associated with autoimmune and autoimmune-related diseases. Vasculitis, embolism, thrombosis, circulating immune complexes and amyloid deposits play a critical role in pathogenesis [34]. Previously, perforations requiring urgent abdominal surgery in the stomach, duodenum, small intestine and colon because of autoimmune diseases have been reported (Table 1) [35,36].

Table 1. Cases requiring abdominal surgery in autoimmune and autoimmune related diseases

\begin{tabular}{lll}
\hline Achalasia & Amyloidosis & Autoimmune hemolytic anemia (IHA) \\
\hline $\begin{array}{l}\text { Esophageal surgery } \\
\text { (myotomy) }\end{array}$ & Gastric Outlet Obstruction & $\begin{array}{c}\text { Benign pelvic neoplasms } \\
\text { Mesenteric teratoma }\end{array}$ \\
& Ischemic colitis & Ovarian teratoma \\
Intestinal hemorrhage & Renal urotepithelial cancer \\
Intestinal pseudo-obstruction & Gallbladder perforation \\
Massive intraperitoneal hemorrhage & Splenectomy & \\
Massive ischemia of the small intestine & Mechanical bowel obstruction & \\
Mesenteric mass & \\
Mimicking colon cancer & \\
Mimicking gallbladder cancer & \\
& Perforation of the sigmoid colon & \\
Pneumatosis intestinalis & \\
Spontaneous hepatic rupture & \\
& Spontaneous rupture of the spleen & \\
Stenosis of ureter &
\end{tabular}

\begin{tabular}{lll}
\hline Addison's disease & Ankylosing spondylitis & Autoimmune hepatitis \\
\hline Acute abdomen & Abdominal aortic aneurysm & $\begin{array}{l}\text { Liver transplantation } \\
\text { Splenic abscesses }\end{array}$ \\
\hline Adult-onset Still's disease & Antiphospholipid Antibody Syndrome & Autoimmune pancreatitis \\
\hline Acute appendicitis & $\begin{array}{l}\text { Acute acalculous cholecystitis } \\
\text { Acute pancreatitis }\end{array}$ & Bowel obstruction \\
& Giant gastric ulceration & Cholangitis \\
& Hepatic artery aneurysm rupture & Choledochal cyst \\
& Massive gangrene of the stomach & Gastric outlet obstruction \\
& Mesenteric ischemia & Inflammatory abdominal aortic \\
& Multiple visceral aneurysms & aneurysm \\
& Recurrent ischemic colitis & Masses in the gallbladder \\
& Splenic thrombosis & Mimicking Cholangiocarcinoma \\
\hline
\end{tabular}




\begin{tabular}{|c|c|c|}
\hline & & $\begin{array}{l}\text { Mimicking Intraductal papillary- } \\
\text { mucinous carcinoma } \\
\text { Mimicking other pancreatic cancers } \\
\text { Obstructive jaundice } \\
\text { Splenomegaly } \\
\text { Pancreatic pseudocyst }\end{array}$ \\
\hline $\begin{array}{l}\text { Autoimmune } \\
\text { polyglandular disease } \\
\text { type I }\end{array}$ & Chagas' disease & Evans syndrome \\
\hline Cholelithiasis & Toxic megacolon & $\begin{array}{l}\text { Intra-abdominal abscess } \\
\text { Splenectomy for thrombocytopenia }\end{array}$ \\
\hline
\end{tabular}

\begin{tabular}{|c|c|c|}
\hline Behcet's Disease & Cogan's syndrome & Giant cell arteritis \\
\hline $\begin{array}{l}\text { Abdominal Aortic } \\
\text { Pseudoaneurysm and } \\
\text { Aneursym } \\
\text { Aortic pseudoaneurysm } \\
\text { rupture into the Sigmoid } \\
\text { colon } \\
\text { Caecal necrosis } \\
\text { Superior Mesenteric and } \\
\text { Celiac Arteries Occlusion }\end{array}$ & Thoracoabdominal aortic aneurysm & $\begin{array}{l}\text { Small bowel infarction } \\
\text { Colon infarction } \\
\text { Involving the female genital tract }\end{array}$ \\
\hline Castleman's Disease & Crohn's disease & $\begin{array}{l}\text { Granulomatosis with Polyangiitis } \\
\text { (Churg-Strauss) }\end{array}$ \\
\hline $\begin{array}{l}\text { Adnexial Mass } \\
\text { Leiomyosarcoma } \\
\text { Intraabdominal mass }\end{array}$ & $\begin{array}{l}\text { Acute pancreatitis } \\
\text { Cholelithiasis } \\
\text { Fistulas (vaginal, bladder, cutaneus, bowel) } \\
\text { Increased risk of colorectal cancer } \\
\text { Increased risk of gallstones } \\
\text { Increased risk of small intestinal cancer } \\
\text { Intestinal hemorrhage } \\
\text { Intestinal obstruction } \\
\text { Intestinal perforation } \\
\text { Intraabdominal abscesses } \\
\text { Multiple liver abscesses } \\
\text { Primary sclerosing cholangitis } \\
\text { Short bowel syndrome (intestinal transplant } \\
\text { surgery) } \\
\text { Strictures of intestine } \\
\text { Toxic megacolon }\end{array}$ & $\begin{array}{l}\text { Appendiceal perforation } \\
\text { Gastrointestinal tract hemorrhage } \\
\text { Intestinal transplantation } \\
\text { Intraabdominal bleeding } \\
\text { Liver infarction } \\
\text { Multiple large-bowel perforations } \\
\text { Pelvic mass leading to total } \\
\text { hysterectomy } \\
\text { Small intestine perforations } \\
\text { Ureteral stenosis }\end{array}$ \\
\hline Celiac disease & Dermatomyositis & Graves' disease \\
\hline $\begin{array}{l}\text { Acute abdominal pain } \\
\text { Small bowel } \\
\text { adenocarcinoma } \\
\text { Small bowel } \\
\text { intussusception } \\
\text { Pneumatosis cystoides } \\
\text { intestinalis }\end{array}$ & $\begin{array}{l}\text { Gastrointestinal perforations } \\
\text { Ischemic duodenal perforated ulcers } \\
\text { Colonic vasculopathy and perforation } \\
\text { Malignant pheochromocytoma } \\
\text { Mimicking ovarian teratoma } \\
\text { Ovarian carcinoma } \\
\text { Primary jejunal neuroendocrine carcinoma } \\
\text { Spontaneous abdominal hematoma }\end{array}$ & $\begin{array}{l}\text { Benign ovarian mass } \\
\text { Malignant struma ovarii }\end{array}$ \\
\hline Guillain-Barré syndrome & IgG4-related autoimmune disease & Myasthenia Gravis \\
\hline Adynamic ileus & $\begin{array}{l}\text { Aortic aneurism ruptures } \\
\text { Cholangitis } \\
\text { Liver abscess and mass } \\
\text { Mimicking Carcinomatosis } \\
\text { Mimicking Klatskin tumour } \\
\text { Mimicking Lymphoma }\end{array}$ & $\begin{array}{l}\text { Abdominal Aortic Aneurysm } \\
\text { Intestinal pseudo-obstruction }\end{array}$ \\
\hline
\end{tabular}


Mimicking Periampullary cancer

Multifocal gastrointestinal varices (bleeding)

Necrotizing mesenteric arteritis

Retroperitoneal fibrosis

Solid pseudopapillary neoplasm of the

Pancreas

Small bowel obstruction

\begin{tabular}{lll}
$\begin{array}{l}\text { Henoch-Schönlein } \\
\text { purpura (HSP) }\end{array}$ & $\begin{array}{l}\text { Lambert-Eaton myasthenic syndrome } \\
\text { Acalculous cholecystitis }\end{array}$ & $\begin{array}{l}\text { Paraneoplastic cerebellar } \\
\text { degeneration }\end{array}$ \\
$\begin{array}{l}\text { Acute appendicitis } \\
\text { Bowel ischaemia and }\end{array}$ & Ovdominal neuroblastoma carcinoma \\
infarction & \\
Gastrointestinal & \\
haemorrhage & \\
Intestinal perforation & \\
Intussusception & \\
Pancreatitis & \\
Terminal ileitis & & \\
\hline
\end{tabular}

\begin{tabular}{lll}
$\begin{array}{l}\text { Idiopathic } \\
\text { thrombocytopenic } \\
\text { purpura (ITP) }\end{array}$ & Microscopic Polyangiitis & $\begin{array}{l}\text { Paroxysmal nocturnal } \\
\text { hemoglobinuria }\end{array}$ \\
\hline $\begin{array}{l}\text { Ovarian carcinoma } \\
\text { Duodenal obstruction } \\
\text { (intamiural hematoma) }\end{array}$ & $\begin{array}{l}\text { Gallbladder hemorrhage } \\
\text { Intestinal ischemia }\end{array}$ & $\begin{array}{l}\text { Abdominal aortic aneurysm } \\
\text { Duodenal obstruction } \\
\text { Gastrointestinal }\end{array}$ \\
hemorrhage & & $\begin{array}{l}\text { Intestinal infarction } \\
\text { Small bowel perforation }\end{array}$ \\
Hemoperitoneum caused & Splenic infarction \\
by a ruptured corpus & \\
luteum & \\
Intra-abdominal bleeding & & \\
Splenectomy & \\
Splenic abscess & \\
Splenic tuberculosis & & \\
\hline
\end{tabular}

Splenic tuberculosis

\begin{tabular}{|c|c|c|}
\hline Pemphigus & Primary sclerosing cholangitis & Sarcoidosis \\
\hline $\begin{array}{l}\text { Retroperitoneal } \\
\text { inflammatory } \\
\text { myofibroblastic tumor } \\
\text { Sigmoid diverticular } \\
\text { perforation }\end{array}$ & $\begin{array}{l}\text { Intraductal papillary neoplasm of the bile } \\
\text { duct } \\
\text { Idiopathic fibrosing pancreatitis } \\
\text { Liver transplantation } \\
\text { Mimicking cholangiocarcinom }\end{array}$ & $\begin{array}{l}\text { Splenectomy for isolated splenic } \\
\text { sarcoidosis }\end{array}$ \\
\hline Pernicious anaemia & Pyoderma gangrenosum & Scleroderma \\
\hline $\begin{array}{l}\text { Gastric carcinoma and } \\
\text { carcinoid tumours }\end{array}$ & Colonic diverticulitis & $\begin{array}{l}\text { Spontaneous bowel perforation } \\
\text { Pneumoperitoneum }\end{array}$ \\
\hline Polymyalgia rheumatica & Relapsing polychondritis & Sclerosing mesenteritis \\
\hline $\begin{array}{l}\text { Abdominal aortic } \\
\text { aneurysm }\end{array}$ & $\begin{array}{l}\text { Abdominal aortic dissection or rupture } \\
\text { Splenic abscess } \\
\text { Surgery for ileocecal ulcers }\end{array}$ & $\begin{array}{l}\text { Intestinal obstruction } \\
\text { Mesenteric ischemia } \\
\text { Mimicking intestinal malignant } \\
\text { neoplasm } \\
\text { Obstructive uropathy } \\
\text { Retroperitoneal tumor }\end{array}$ \\
\hline Polymyositis & Retroperitoneal fibrosis & Sjögren's syndrome \\
\hline $\begin{array}{l}\text { Ovarian carcinoma } \\
\text { Pancreatic cancer } \\
\text { Sigmoid colon perforation } \\
\text { Simulating primary } \\
\text { hyperaldosteronism }\end{array}$ & $\begin{array}{l}\text { Duodenal and intestinal obstruction } \\
\text { Huge splenomegaly } \\
\text { Inflammatory abdominal aortic aneurysm } \\
\text { Urethral obstruction }\end{array}$ & $\begin{array}{l}\text { Idiopathic fibrosing pancreatitis } \\
\text { Idiopathic retroperitoneal fibrosis } \\
\text { Intra-abdominal hemorrhage } \\
\text { Mesenteric acute panniculitis } \\
\text { Pancreatic pseudotumor } \\
\text { Splenic abscess }\end{array}$ \\
\hline
\end{tabular}




\begin{tabular}{|c|c|c|}
\hline Primary biliary cirrhosis & Rheumatoid arthritis (RA) & Systemic sclerosis \\
\hline $\begin{array}{l}\text { Hepatocellular carcinoma } \\
\text { Idiopathic fibrosing } \\
\text { pancreatitis } \\
\text { Liver transplantation }\end{array}$ & $\begin{array}{l}\text { Acute cholecystitis } \\
\text { Amyloidosis of the small intestine } \\
\text { Endometrial cancer } \\
\text { Increased frequency of gallbladder Stones } \\
\text { Obstructive eosinophilic gastroenteritis } \\
\text { Sigmoid colon perforation } \\
\text { Small and large intestinal infarction } \\
\text { Small bowel stricture } \\
\text { Vasculitis of the female genital tract }\end{array}$ & Female genital tract cancer \\
\hline $\begin{array}{l}\text { Systemic lupus } \\
\text { erythematosus (SLE) }\end{array}$ & Wegener's granulomatosis & Ulcerative colitis \\
\hline $\begin{array}{l}\text { Acute abdomen } \\
\text { Acute acalculous } \\
\text { cholecystitis } \\
\text { Aortic aneurysm and } \\
\text { dissection } \\
\text { Aortic occlusion } \\
\text { Acute pancreatitis } \\
\text { Choledochal cyst } \\
\text { End-stage Renal disease } \\
\text { (renal transplantation) } \\
\text { Hemorrhagic cholecystitis } \\
\text { and hemobilia } \\
\text { Hepatic artery aneurysm } \\
\text { Ileocecal intussusception } \\
\text { Intestinal ischemia } \\
\text { Intestinal perforation } \\
\text { Intestinal pseudo- } \\
\text { obstruction } \\
\text { Spontaneous perinephric } \\
\text { hemorrhage }\end{array}$ & $\begin{array}{l}\text { Acute pancreatitis } \\
\text { Aortitis with aneurysm formation } \\
\text { Intestinal ischemia } \\
\text { Small bowel perforation } \\
\text { Splenic abscess } \\
\text { Spontaneous splenic hemorrhage }\end{array}$ & $\begin{array}{l}\text { Acute pancreatitis } \\
\text { Colon obstruction } \\
\text { Colon perforation } \\
\text { Cholangiocarcinoma toxic megacolon } \\
\text { Cholelithiasis } \\
\text { Chronic pancreatitis } \\
\text { Fistulas (vaginal, bladder, cutaneus) } \\
\text { Fulminant/refractory colitis } \\
\text { Hemangioma } \\
\text { Increased risk of colorectal cancer } \\
\text { Intestinal hemorrhage } \\
\text { Mucosal lesions in duodenum } \\
\text { Primary sclerosing cholangitis } \\
\text { Stricture of colon }\end{array}$ \\
\hline
\end{tabular}

\section{Tolosa-Hunt syndrome}

Mycotic aortic aneurysm

Depending on the gastric involvement of autoimmune and autoimmune-related diseases, complications including gastric ulcer, necrosis and gastric outlet obstruction can be observed. Subtotal or total gastrectomies could be required for the treatment of these complications [37,38]. Paralytic or mechanical ileus is another clinical condition associated with autoimmune and autoimmune-related diseases in which abdominal surgery is not required in the majority of the cases of paralytic pseudo-obstruction, while the surgical treatments are needed in mechanical intestinal obstruction. Therefore, the differential diagnosis of ileus is important to avoid unnecessary surgery. Guillain-Barré syndrome, systemic lupus erythematosus, myasthenia gravis paralytic ileus can be observed $[39,40]$. Chagas' disease is an endemic disease which is caused by Trypanosoma cruzini, and it particularly affects Latin American countries. However, previous studies have suggested the autoimmunity hypothesis, i.e. the disease may have an autoimmune pathogenesis $[41,42]$. The disease is also on the list provided by the American Autoimmune Related Diseases Association (AARDA) (https://www.aarda.org/diseaselist/). Although the megacolon, which is a long-term complication of
Chagas' disease, has ileus findings, there is no mechanical obstruction. Yet, colon resection may be still required in the treatment [43]. The causes such as intussusception, fibrosis-related stricture, abnormal eosinophilic infiltration of the gastrointestinal tract, amyloid deposition, mesenteric vasculitis and intramural hematoma are related to the etiopathogenesis of autoimmune disease-related mechanical intestinal obstruction [44,45]. Principally in children, intussusceptions causing mechanical intestinal obstruction have been seen in patients with HenochSchonlein purpura, celiac disease and systemic lupus erythematosus $[46,47]$.

The gastrointestinal system involvement of autoimmune and autoimmune-related diseases can be the reason of bleeding in the gastrointestinal tract which leads to an increased mortality and morbidity. Surgical interventions are often used besides endoscopic and angiographic procedures for hemostasis. The etiopathogenesis of gastrointestinal bleeding is associated with vasculitis, thrombocytopenia, mucosal ischemia and gastrointestinal varices [48]. Massive gastrointestinal bleeding can be observed especially in idiopathic 
thrombocytopenic purpura and Henoch-Schönlein purpura $[49,50]$. In addition to gastrointestinal bleeding, intraabdominal bleeding, which can develop due to solid organ ruptures and postoperative bleeding, is accompanied by some autoimmune diseases [51]. A case report of spontaneous hepatic rupture causing intraabdominal bleeding due to amloidosis has been previously noted [52].

Thromboembolic complications occurring in solid organs, small intestines, and the colon are an important clinical condition caused by autoimmune and autoimmunerelated diseases. Vasculitis, vascular thrombosis of veins and arteries are related to etiopathogenesis [53,54]. Ischemia and necrosis eventually develop in the organs as a result of this complication. Emergency abdominal surgeries may be required in case of ischemia and necrosis. Antiphospholipid Syndrome, giant-cell arteritis, systemic lupus erythematosus and paroxysmal nocturnal hemoglobinuria are the most commonly observed autoimmune diseases [55-57]. Throboembolic complications and organ ischemia have also been reported in Behcet's Disease, Churg-Strauss syndrome, HenochSchönlein purpura and Wegener's granulomatosis (Table 1) $[58,59]$.

Acute appendicitis can develop as a complication of autoimmune diseases such as Eosinophilic Granulomatosis with Polyangiitis (Churg-Strauss) and Henoch-Schönlein purpura. Appendectomy is the treatment of choice for acute appendicitis [60]. Systemic lupus erythematosus can also be involved in the Necrotizing vasculitis of the appendix [61]. Mesenteric acute panniculitis and acute appendicitis related clinical findings can be observed in Sjögren's syndrome [62].

Some autoimmune and autoimmune-related diseases can lead to surgical procedures because of spleen-related involvements. Clinical conditions which require splenectomy are often encountered. Splenectomy is performed for both the remission and the treatment of autoimmune hemolytic anemia and idiopathic thrombocytopenic purpura. Splenectomy has been previously performed for splenic abscesses in autoimmune hepatitis, Sjögren syndrome, relapsing polychondritis, and Wegener's granulomatosis [63]. Splenectomy is also performed in the case of isolated splenic involvement in sarcoidosis, splenic necrosis and rupture in Wegener's granulomatosis (Table 1) [9,64]. Autoimmune and autoimmune-related diseases can lead to gallbladderrelated pathologies, such as acute acalculous cholecystitis, cholelithiasis, eosinophilic cholecystitis, vasculitis of the gallbladder, hemorrhagic cholecystitis and hemobilia (Table 1). An increased incidence of gallbladder stones was observed in patients with rheumatoid arthritis [65]. Acute acalculous cholecystitis has also been reported as a gastrointestinal manifestation of systemic lupus erythematosus in various case reports. While the majority of the cases were treated by means of cholecystectomy, several cases successfully treated with corticosteroid have also been reported [66]. Few cases of microscopic polyangiitis and systemic lupus erythematosus with hemorrhagic cholecystitis and gallbladder hemorrhage caused by vasculitis have also been reported. Cholecystectomy was performed to these patients $[67,68]$.

It is well known that pancreatitis is associated with many autoimmune diseases. But, abdominal surgery is not commonly required in the treatment of most cases with pancreatitis [69]. Since acute pancreatitis is also related to the acute abdomen, it should be clearly distinguished from the clinical conditions requiring urgent abdominal surgery. However, in the case of acute pancreatitis, pseudocyst, infected necrosis, abscess and bleeding, abdominal surgeries may still be required [70]. The examples of autoimmune diseases associated with pancreatitis include autoimmune pancreatitis, antiphospholipid syndrome, Wegener's granulomatosis, Henoch-Schönlein purpura, ulcerative colitis, Sjögren's syndrome, primary biliary cirrhosis and primary sclerotic cholangitis [71,72].

Reactions emerged on the topic of autoimmune and autoimmune-related diseases which can cause intraabdominal tumor masses which often mimic malignant tumors, and sometimes result in unnecessary or radical abdominal surgeries. On the other hand, some autoimmune diseases have been found to be associated with malignant tumors. For example, abdominal surgeries have been performed for the paraneoplastic intraabdominal, retroperitoneal tumor masses associated with Castleman's Disease, granulomatosis with polyangiitis, autoimmune pancreatitis, pemphigus, sclerotic mesenteritis and Sjogren's syndrome [73-75]. Moreover, a relationship between some autoimmune diseases and tumor masses has been reported in several studies. For instance, associations between Graves' disease and struma ovarii, between autoimmune hemolytic anemia and ovarian teratoma, between idiopathic thrombocytopenic purpura and ovarian carcinoma, between paraneoplastic cerebellar degeneration and ovarian carcinoma and, between pernicious anemia and gastric cancer have been commonly shown as clinical conditions in the literature [76-79]. Because autoimmune diseases may occasionally mimic malignant tumors, this situation leads to misdiagnosis and treatment as in the example of autoimmune pancreatitis and pancreatic cancer differentiation. The differentiation is particularly difficult due to similar clinical presentations, laboratory results and morphologic imaging [80]. Another example is primary sclerotic cholangitis which mimics cholangiocarcinoma [81]. Similar relationships have been also reported between various autoimmune diseases and malignant tumors (Table 1).

Achalasia is a neurodegenerative disorder that develops because of the dysfunction of the lower esophageal 
sphincter in the case of myenteric plexus loss. Myotomy performed with minimally invasive surgery methods in the treatment of achalasia treatment has been reported to have a higher success rate [82].

Many of the autoimmune and autoimmune-related diseases can involve the main vascular and visceral vascular structures, such as the aorta (Table 1). Moreover, an increased incidence in inflammatory aortic aneurysm has been observed in autoimmune and autoimmune-related diseases [83]. Rupture and aortic dissection due to aortic aneurysm requiring emergency abdominal surgery are among the clinical cases with high mortality rates. Hepatic artery aneurysm bleeding, which requires urgent abdominal surgery, has also been previously reported in systemic lupus erythematosus and antiphospholipid syndrome [84].

Complications such as ureter stenosis and ureteric obstruction may also develop depending on the ureter involvement of autoimmune and autoimmune-related diseases. Furthermore, some autoimmune diseases have been found to be associated with renal urothelial cancer. Abdominal surgery is required in the treatment of such clinical conditions [85-87]. Several complications requiring abdominal surgery may also develop as a result of the type of medical treatment of autoimmune and autoimmune-related diseases [88], as in the example of bowel perforations developing in a patient receiving a high-dose steroid treatment due to Churg-Strauss syndrome [89]. In addition, a case of intestinal necrosis in a patient receiving an anti-TNF treatment due to rheumatoid arthritis has also been reported [90].

\section{Conclusions}

Taking all these into consideration, autoimmune and autoimmune-related diseases can also influence the abdominal organs. The influence may be directly related to the involvement of the organ and system as a result of autoimmune disease or indirectly related to the influence of the organs and systems. Such influence leading to complications may require urgent or elective abdominal surgery, which can further cause high mortality and morbidity. Therefore, it is significant for all clinicians, especially surgeons, to be aware of the relationship between autoimmune diseases and abdominal surgery. The early detection and treatment of the complications related to the abdominal involvement of autoimmune and autoimmune-related diseases could decrease mortality and morbidity.

\section{Conflict of interest disclosure}

There are no known conflicts of interest in the publication of this article. The manuscript was read and approved by all authors.

\section{Compliance with ethical standards}

Any aspect of the work covered in this manuscript has been conducted with the ethical approval of all relevant bodies and that such approvals are acknowledged within the manuscript.

\section{References}

1. Wang L, Wang FS, Gershwin ME. Human autoimmune diseases: a comprehensive update. J Intern Med. 2015 Oct;278(4):369-95. doi: 10.1111/joim.12395

2. Eaton WW, Rose NR, Kalaydjian A, Pedersen MG, Mortensen PB. Epidemiology of autoimmune diseases in Denmark. J Autoimmun. 2007 Aug;29(1):1-9. doi: 10.1016/j.jaut.2007.05.002

3. Espinosa G, Cervera R. Antiphospholipid syndrome: frequency, main causes and risk factors of mortality. Nat Rev Rheumatol. 2010 May;6(5):296-300. doi: 10.1038/nrrheum.2010.47

4. Ocampo-Piraquive V, Nieto-Aristizábal I, Cañas CA, Tobón GJ. Mortality in systemic lupus erythematosus: causes, predictors and interventions. Expert Rev Clin Immunol. 2018 Dec;14(12):1043-1053. doi: 10.1080/1744666X.2018.1538789

5. Miniter U, Bae-Harboe YS, Powers JG, Campbell SM, Goldberg LJ. Fatal Henoch-Schonlein purpura in an adult related to bowel perforation: report and review of the literature. Dermatol Online J. 2012 Oct 15;18(10):9.

6. Stupalkowska W, Mahler-Araujo B, Bennett J, Gourgiotis S. Spontaneous bowel perforation in the setting of colonic involvement with scleroderma. $B M J$ Case Rep. 2020 Jan 5;13(1):e233220. doi: 10.1136/bcr2019-233220

7. Yuan SM. Aortic aneurysm and dissection in systemic lupus erythematosus. Z Rheumatol. 2019 Apr;78(3): 287-294. doi: 10.1007/s00393-018-0555-x

8. Renzulli P, Schoepfer A, Mueller E, Candinas D. Atraumatic splenic rupture in amyloidosis. Amyloid. 2009;16(1):47-53. doi: 10.1080/13506120802676922

9. Souto MM, Tempes BC, Lambert BF, Trindade EN, Trindade MR. Laparoscopic splenectomy for isolated splenic sarcoidosis. JSLS. 2014 Jan-Mar;18(1):155-9. doi: 10.4293/108680814X13868878212956

10. Scoglio D, Ahmed Ali U, Fichera A. Surgical treatment of ulcerative colitis: ileorectal vs ileal pouchanal anastomosis. World J Gastroenterol. 2014 Oct 7;20(37):13211-8. doi: 10.3748/wjg.v20.i37.13211

11. Carbone M, Neuberger JM. Autoimmune liver disease, autoimmunity and liver transplantation. J Hepatol. 2014;60(1):210-23. doi: 10.1016/j.jhep.2013.09.020

12. Memon AW, Siddiqui S, Hamza A. Autoimmune Disease Presenting As Acute Abdomen. J Ayub Med Coll Abbottabad. 2017 Jan-Mar;29(1):139-141. 
13. Brewer BN, Kamen DL. Gastrointestinal and Hepatic Disease in Systemic Lupus Erythematosus. Rheum Dis Clin North Am. 2018 Feb;44(1):165-175. doi: 10.1016/j.rdc.2017.09.011

14. Miyabe K, Zen Y, Cornell LD, Rajagopalan G, Chowdhary VR, Roberts LR, Chari ST. Gastrointestinal and Extra-Intestinal Manifestations of IgG4-Related Disease. Gastroenterology. 2018;155(4): 990-1003.e1. doi: 10.1053/j.gastro.2018.06.082

15. Lecouffe-Desprets M, Groh M, Bour B, Le Jeunne C, Puéchal X. Eosinophilic gastrointestinal disorders associated with autoimmune connective tissue disease. Joint Bone Spine. 2016 Oct;83(5):479-84. doi: 10.1016/j.jbspin.2015.11.006

16. Strasser S, Sheil AG, Gallagher ND, Waugh R, McCaughan GW. Liver transplantation for primary sclerosing cholangitis versus primary biliary cirrhosis: a comparison of complications and outcome. J Gastroenterol Hepatol. 1993 May-Jun;8(3):238-43. doi: 10.1111/j.1440-1746.1993.tb01193.x

17. Naranjo-Escobar J, Manzi E, Posada JG, Mesa L, Echeverri GJ, Duran C, Schweneiberg J, Caicedo LA, Villegas JI, Tobón GJ. Kidney transplantation for endstage renal disease in lupus nephritis, a very safe procedure: a single Latin American transplant center experience. Lupus. 2017 Oct;26(11):1157-1165. doi: $10.1177 / 0961203317696591$

18. Darius T, Monbaliu D, Aerts R, Coosemans W, de Roey J, Blockmans D, Hiele M, Van Assche G, Ferdinande P, Dierickx D, Ectors N, Lerut E, De Hertogh G, Benedetti E, Pirenne J. Living related intestinal transplantation for Churg-Strauss syndrome: a case report. Transplant Proc. 2010 Dec;42(10):44234. doi: 10.1016/j.transproceed.2010.07.015

19. Ko IK, Kim BG, Awadallah A, Mikulan J, Lin P, Letterio JJ, Dennis JE. Targeting improves MSC treatment of inflammatory bowel disease. Mol Ther. 2010 Jul;18(7):1365-72. doi: 10.1038/mt.2010.54

20. Feuerstein JD, Jiang ZG, Belkin E, Lewandowski JJ, Martinez-Vazquez M, Singla A, Cataldo T, Poylin V, Cheifetz AS. Surgery for Ulcerative Colitis Is Associated with a High Rate of Readmissions at 30 Days. Inflamm Bowel Dis. 2015 Sep;21(9):2130-6. doi: 10.1097/MIB.0000000000000473

21. Fornaro R, Caratto M, Barbruni G, Fornaro F, Salerno A, Giovinazzo D, Sticchi C, Caratto E. Surgical and medical treatment in patients with acute severe ulcerative colitis. J Dig Dis. 2015 Oct;16(10):558-67. doi: 10.1111/1751-2980.12278

22. Frunza TC, Lunca S, Baciu I, Axinia I, Mocanu CV, Crudu A, Bujor N, Livenschi LF, Nicolaiev CA, Hulubencu A, Diaconu A, Valasciu E, Jalobceastai I, Tibirna M, Dimofte MG. LARS-like symptoms in the general population may suggest the significance of postoperative functional problems and emotional implications of rectal surgery. J Mind Med Sci. 2019; 6(2):278-285. doi: 10.22543/7674.62.P278285

23. Olén O, Erichsen R, Sachs MC, Pedersen L, Halfvarson J, Askling J, Ekbom A, Sørensen HT, Ludvigsson JF. Colorectal cancer in ulcerative colitis: a Scandinavian population-based cohort study. Lancet. 2020 Jan 11;395(10218):123-131. doi: 10.1016/S01406736(19)32545-0

24. Ichikawa T, Sadahiro S, Yuhara H, Suzuki T, Igarashi M, Mine T, Tomita S, Imai Y. A Case of Colon Cancer Associated with Ulcerative Colitis: Evaluation Using CT Colonography. Tokai J Exp Clin Med. 2015 Sep 20;40(3):104-9.

25. Chong VF, Heng A. Cholangiocarcinoma complicating ulcerative colitis. Ann Acad Med Singap. 1993 Sep;22(5):798-801.

26. Fousekis FS, Katsanos KH, Theopistos VI, Baltayiannis G, Kosmidou M, Glantzounis G, Christou L, Tsianos EV, Christodoulou DK. Hepatobiliary and pancreatic manifestations in inflammatory bowel diseases: a referral center study. BMC Gastroenterol. 2019 Apr 3;19(1):48. doi: 10.1186/s12876-019-0967-3

27. Smida M, Miloudi N, Hefaiedh R, Zaibi R. Emergency surgery for Crohn's disease. Tunis Med. 2016 Mar;94(3):210-5.

28. Olén O, Erichsen R, Sachs MC, Pedersen L, Halfvarson J, Askling J, Ekbom A, Sørensen HT, Ludvigsson JF. Colorectal cancer in Crohn's disease: a Scandinavian population-based cohort study. Lancet Gastroenterol Hepatol. 2020 May;5(5):475-484. doi: 10.1016/S24681253(20)30005-4

29. Navaneethan U, Shen B. Hepatopancreatobiliary manifestations and complications associated with inflammatory bowel disease. Inflamm Bowel Dis. 2010 Sep;16(9):1598-619. doi: 10.1002/ibd.21219

30. Trikudanathan G, Venkatesh PG, Navaneethan U. Diagnosis and therapeutic management of extraintestinal manifestations of inflammatory bowel disease. Drugs. 2012 Dec 24;72(18):2333-49. doi: 10.2165/11638120-000000000-00000

31. Thyø AA, Lausten SB. Mb. Addison's disease causing acute abdomen. Ugeskr Laeger. 2012 May 21;174(21):1458-9.

32. Wakiyama S, Yoshimura K, Shimada M, Sugimachi K. Lupus peritonitis mimicking acute surgical abdomen in a patient with systemic lupus erythematosus: report of a case. Surg Today. 1996;26(9):715-8. doi: 10.1007/BF00312091

33. Sanders DS, Hopper AD, Azmy IA, Rahman N, Hurlstone DP, Leeds JS, George RR, Bhala N. Association of adult celiac disease with surgical abdominal pain: a case-control study in patients 
referred to secondary care. Ann Surg. 2005;242(2):201-

7. doi: 10.1097/01.sla.0000171301.35513.cf

34. Lerkvaleekul B, Treepongkaruna S, Saisawat P, Thanachatchairattana P, Angkathunyakul N, Ruangwattanapaisarn N, Vilaiyuk S. HenochSchönlein purpura from vasculitis to intestinal perforation: A case report and literature review. World J Gastroenterol. 2016 Jul 14;22(26):6089-94. doi: 10.3748/wjg.v22.i26.6089

35. Gu Y, Zhu T, Wang Y, Xu H. Systemic lupus erythematosus with intestinal perforation: A case report. Exp Ther Med. 2015 Sep;10(3):1234-1238. doi: 10.3892/etm.2015.2639

36. Eriksson P, Segelmark M, Hallböök O. Frequency, Diagnosis, Treatment, and Outcome of Gastrointestinal Disease in Granulomatosis with Polyangiitis and Microscopic Polyangiitis. J Rheumatol. 2018 Apr;45(4):529-537. doi: 10.3899/jrheum.170249

37. Srivastava V, Basu S, Ansari M, Gupta S, Kumar A. Massive gangrene of the stomach due to primary antiphospholipid syndrome: report of two cases. Surg Today. 2010;40(2):167-70. doi: 10.1007/s00595-0094015-8

38. Soni SC, Mehta N, Ray S, Nundy S. Intra-abdominal hypertension and abdominal compartment syndrome in patients undergoing gastrointestinal surgery. $J$ Clin Invest Surg. 2019;4(2):101-107. doi: 10.25083/2559.5555/4.2/101.107

39. Musthafa CP, Moosa A, Chandrashekharan PA, Nandakumar R, Narayanan AV, Balakrishnan V. Intestinal pseudo-obstruction as initial presentation of thymoma. Indian $J$ Gastroenterol. 2006 SepOct;25(5):264-5.

40. Jin P, Ji X, Zhi H, Song X, Du H, Zhang K, Shao R, Ge S, Chen Q, Lu H, Lu J. A review of 42 cases of intestinal pseudo-obstruction in patients with systemic lupus erythematosus based on case reports. Hum Immunol. 2015 Sep;76(9):695-700. doi: 10.1016/j.humimm.2015.09.022

41. Kierszenbaum F. Where do we stand on the autoimmunity hypothesis of Chagas disease? Trends Parasitol. 2005 Nov;21(11):513-6. doi: 10.1016/j.pt.2005.08.013

42. Bonney KM, Engman DM. Autoimmune pathogenesis of Chagas heart disease: looking back, looking ahead. Am J Pathol. 2015 Jun;185(6):1537-47. doi: 10.1016/j.ajpath.2014.12.023

43. Netinho JG, Cunrath GS, Ronchi LS. Rectosigmoidectomy with ileal loop interposition: a new surgical method for the treatment of chagasic megacolon. Dis Colon Rectum. 2002 Oct;45(10):138792. doi: 10.1097/01.DCR.0000027061.67224.C8

44. Oyama G, Tomita M, Matsuo T, Inada Y, Osaka H, Kiriyama M, Yoneda K, Takagawa K, Tsuji H.
Autoimmune pancreatitis with bowel obstruction caused by proximal jejunal stricture:a case report. Nihon Shokakibyo Gakkai Zasshi. 2019;116(3):256264. doi: 10.11405/nisshoshi.116.256

45. Tago M, Naito Y, Aihara H, Furukawa NE, Yamashita S. Recurrent Stenosis of the Ileum Caused by Rheumatoid Vasculitis. Intern Med. 2016;55(7):81923. doi: 10.2169/internalmedicine.55.5791

46. Cerrah Celayir A, Celayir S, Kutlu T. The role of surgery in the treatment of instussusception in celiac disease. Turk J Gastroenterol. 2002 Mar;13(1):63-5.

47. Little KJ, Danzl DF. Intussusception associated with Henoch-Schonlein purpura. J Emerg Med. 1991;9 Suppl 1:29-32. doi: 10.1016/0736-4679(91)90584-3

48. Lin TC, Chang WL. Multifocal gastrointestinal varices: a rare manifestation of immunoglobulin G4-related disease. Postgrad Med. 2019 Apr;131(3):176-181. doi: 10.1080/00325481.2019.1568018

49. Chang WL, Yang YH, Lin YT, Chiang BL. Gastrointestinal manifestations in Henoch-Schönlein purpura: a review of 261 patients. Acta Paediatr. 2004; 93(11):1427-31. doi: 10.1080/08035250410020181

50. Teramura M, Mizoguchi H. Emergency treatment of severe bleeding in idiopathic thrombocytopenic purpura. Nihon Rinsho. 2003 Apr;61(4):629-31.

51. Kaplan J, Bannon CC, Hulse M, Freiberg A. Peritoneal hemorrhage due to a ruptured ovarian cyst in ITP. $J$ Pediatr Hematol Oncol. 2007 Feb;29(2):117-20. doi: 10.1097/MPH.0b013e3180314206

52. Lehmann TG, Scheble V, Miller S, Heininger A, Fend F, Koenigsrainer A. Spontaneous hepatic rupture in amyloidosis - report of a case. Z Gastroenterol. 2012 Dec;50(12):1296-301. doi: 10.1055/s-0032-1325340

53. Passam FH, Diamantis ID, Perisinaki G, Saridaki Z, Kritikos H, Georgopoulos D, Boumpas DT. Intestinal ischemia as the first manifestation of vasculitis. Semin Arthritis Rheum. 2004 Aug;34(1):431-41. doi: 10.1016/j.semarthrit.2003.12.004

54. Quentin V, Dinasquet M, Rioux-Leclercq N, de Lajarte-Thirouard AS, Lotrian D, Lamy T, Bernard M, Olivié D, Gosselin M, Bretagne JF, Heresbach D. Paroxysmal nocturnal hemoglobinuria associated with intestinal ischemia leading to small bowel perforation. Gastroenterol Clin Biol. 2003 Oct;27(10):927-31.

55. Wang QY, Ye XH, Ding J, Wu XK. Segmental small bowel necrosis associated with antiphospholipid syndrome: a case report. World J Gastroenterol. 2015;21(13):4096-100. doi: 10.3748/wjg.v21.i13.4096

56. Kalbermatter V, Laudanno C, Bagilet D, Diab M, Giménez D, Serra F. Intestinal infarct caused by giant cell arteritis. Medicina (B Aires). 1999;59(1):86-9.

57. Vergara-Fernandez O, Zeron-Medina J, Mendez-Probst C, Salgado-Nesme N, Borja-Cacho D, Sanchez- 
Guerrero J, Medina-Franco H. Acute abdominal pain in patients with systemic lupus erythematosus. $J$ Gastrointest Surg. 2009 Jul;13(7):1351-7. doi: 10.1007/s11605-009-0897-4

58. Shahverdi E, Morshedi M, Oraei-Abbasian F, Allahverdi Khani M, Khodayarnejad R. A Rare Case of Vasculitis Patched Necrosis of Cecum due to Behçet's Disease. Case Rep Surg. 2017;2017:1693737. doi: $10.1155 / 2017 / 1693737$

59. Storesund B, Gran JT, Koldingsnes W. Severe intestinal involvement in Wegener's granulomatosis: report of two cases and review of the literature. $\mathrm{Br} J$ Rheumatol. 1998 Apr;37(4):387-90. doi: 10.1093/rheumatology/37.4.387

60. Binstadt BA, Fleegler EW. Perforated appendicitis in a child with Henoch-Schönlein purpura. J Pediatr Surg. 2005;40(2):E24-7. doi: 10.1016/j.jpedsurg.2004.10.002

61. Schmidt WA, Schneider W, Gromnica-Ihle EJ. Necrotizing vasculitis of the appendix and cecum in systemic lupus erythematosus. Z Rheumatol. 1996 JulAug;55(4):267-71.

62. Sugihara T, Koike R, Nosaka Y, Ogawa J, Hagiyama H, Nagasaka K, Nonomura Y, Nishio J, Nanki T, Kohsaka H, Kubota T, Miyasaka N. Case of subcutaneous and mesenteric acute panniculitis with Sjögren's syndrome. Nihon Rinsho Meneki Gakkai Kaishi. 2002;25(3):277-84. doi: 10.2177/jsci.25.277

63. Albanopoulos K, Archontovassilis F, Alexakis N, Pantelidaki A, Bramis C, Leandros E. Splenic abscess in a patient with Wegener's granulomatosis treated with laparoscopic splenectomy. Mt Sinai J Med. 2006 Nov;73(7):1045-8.

64. Kettritz R, Anders S, Kettritz U, Schneider W, Göbel U, Luft FC. Spontaneous splenic hemorrhage in a patient with Wegener's granulomatosis. Am J Kidney Dis. 1998 May;31(5):860-2. doi: 10.1016/s02726386(98)70058-7.

65. Pamuk ON, Umit H, Unlü E, Köker IH, Cakir N. An increased frequency of gallbladder stones in rheumatoid arthritis patients. Factors related to gallbladder stone formation. Clin Exp Rheumatol. 2006 May-Jun;24(3):317-20.

66. Kamimura T, Mimori A, Takeda A, Masuyama J, Yoshio T, Okazaki H, Kano S, Minota S. Acute acalculous cholecystitis in systemic lupus erythematosus: a case report and review of the literature. Lupus. 1998;7(5):361-3. doi: $10.1191 / 096120398678920154$

67. García Pérez R, Ruiz de Angulo D, López Poveda MJ, Febrero Sánchez B, Navas Carrillo D, Parrilla Paricio P. Hemorrhagic cholecystitis and hemobilia: two infrequent complications of systemic lupus erythematosus. Rev Esp Enferm Dig. 2011 Aug; 103(8): 431-3. doi: 10.4321/s1130-01082011000800009
68. Kitaguchi D, Kurata M, Shimomura O, Oda T, Ohkohchi N. Gallbladder bleeding associated with microscopic polyangiitis: a case report. J Surg Case Rep. 2017;2017(8):rjx159. doi: 10.1093/jscr/rjx159

69. Pickartz T, Mayerle J, Lerch MM. Autoimmune pancreatitis. Nat Clin Pract Gastroenterol Hepatol. 2007 Jun;4(6):314-23. doi: 10.1038/ncpgasthep0837

70. Zhang K, Liu X, Yi L, Li J, Shi J, Liu T. A case report of autoimmune pancreatitis associated with a pancreatic pseudocyst. Medicine (Baltimore). 2018;97(19): e0439. doi: 10.1097/MD.0000000000010439

71. Nve E, Ribé D, Navinés J, Villanueva MJ, Franch G, Torrecilla A, Blay J, Badia JM. Idiopathic fibrosing pancreatitis associated with ulcerative colitis. HPB (Oxford). 2006;8(2):153-5. doi: $10.1080 / 13651820600686998$

72. Madhani K, Farrell JJ. Autoimmune Pancreatitis: An Update on Diagnosis and Management. Gastroenterol Clin North Am. 2016 Mar;45(1):29-43. doi: 10.1016/j.gtc.2015.10.005

73. Schelble AP, Merritt DF. Pelvic Castleman's Disease Presenting as an Adnexal Mass in an Adolescent. $J$ Pediatr Adolesc Gynecol. 2019 Feb;32(1):86-89. doi: 10.1016/j.jpag.2018.09.002

74. Ghaleb M, Bouaziz H, Sghaier S, Slimane M, Bouzaiene H, Ben Hassouna J, Ben Dhiab T, Hechiche M, Chargui R, Rahal K. Ovarian cancer: Is an expert surgical oncologist mandatory? J Clin Invest Surg. 2019;4(2):58-65. doi: 10.25083/2559.5555/4.2/58.65

75. Beristain JL, Sabater L, Calatayud A, Calvete J, Rausell M, Lledó S, Tosca J, Sastre J, Aparisi L. Autoimmune pancreatitis: inflammatory pseudotumor, multifocal fibrosclerosis, portal hypertension, and long-term outcome. Rev Esp Enferm Dig. 2008 Oct;100(10):6528.

76. Pastorino Casas V, Borghi Torzillo MF, Schere D, Lutfi RJ, Faure EN. Struma ovarii associated with Graves' disease. Medicina (B Aires). 2018;78(1):44-46.

77. Kim I, Lee JY, Kwon JH, Jung JY, Song HH, Park YI, Ro E, Choi KC. A case of autoimmune hemolytic anemia associated with an ovarian teratoma. J Korean Med Sci. 2006 Apr;21(2):365-7. doi: 10.3346/jkms.2006.21.2.365

78. Slavu I, Alecu L, Tulin A, Stanculeanu DL, Nitipir C. Laparoscopic resection of gastric GISTs. Where do we stand now? A single-centered experience. J Mind Med Sci. 2019;6(2):334-339. doi: 10.22543/7674.62.P334339

79. Lahner E, Capasso M, Carabotti M, Annibale B. Incidence of cancer (other than gastric cancer) in pernicious anaemia: A systematic review with metaanalysis. Dig Liver Dis. 2018 Aug;50(8):780-786. doi: 10.1016/j.dld.2018.05.012

80. Li G, Liu T, Zheng J, Kang W, Xu J, Gao Z, Ma J. Untypical autoimmune pancreatitis and pancreatic 
cancer: differential diagnosis experiences extracted from misdiagnose of two cases. Orphanet J Rare Dis. 2019 Nov 7;14(1):245. doi: 10.1186/s13023-019-1217-z

81. Lee JJ, Schindera ST, Jang HJ, Fung S, Kim TK. Cholangiocarcinoma and its mimickers in primary sclerosing cholangitis. Abdom Radiol (NY). 2017 Dec;42(12):2898-2908. doi: 10.1007/s00261-0171328-8

82. Gockel I, Gith A, Drescher D, Jungmann F, Eckhard L, Lang H. Minimally invasive surgery for achalasia in patients >40 years: more favorable than anticipated. Langenbecks Arch Surg. 2012 Jan;397(1):69-74. doi: 10.1007/s00423-011-0832-5

83. Haug ES, Skomsvoll JF, Jacobsen G, Halvorsen TB, Saether OD, Myhre HO. Inflammatory aortic aneurysm is associated with increased incidence of autoimmune disease. J Vasc Surg. 2003 Sep;38(3):492-7. doi: 10.1016/s0741-5214(03)00340-9

84. Liu C, Tang QB, Zeng H, Yu XH, Xu LB, Li Y. Clinical and pathological analysis of hepatic artery aneurysm in a patient with systemic lupus erythematosus: report of a case. Surg Today. 2011 Nov;41(11):1571-4. doi: 10.1007/s00595-010-4470-2

85. Tremps Velázquez E, Ramón Dalmau M, García Rojo D, Cambra Bonastre V, Rodríguez de Ledesma Vega JM. Ureteral stenosis secondary to Churg-Strauss allergic granulomatous vasculitis. Arch Esp Urol. 1997 Jan-Feb;50(1):82-4.
86. Bjorndalen H, Hastings RA. Ureteric obstruction secondary to retroperitoneal fibrosis leading to acute kidney injury. BMJ Case Rep. 2013 Feb 5; 2013:bcr2012008093. doi: 10.1136/bcr-2012-008093

87. Isotani S, Horiuchi A, Koja M, Noguchi T, Sugiura S, Shimoyama H, Noma Y, Kitamura K, China T, Tokiwa S, Saito K, Kimura M, Hisasue S, Ide H, Muto S, Yamaguchi R, Horie S. Autoimmune hemolytic anemia associated with renal urothelial cancer: A case report and literature review. BMC Urol. 2015 Jul 28;15:75. doi: 10.1186/s12894-015-0071-0

88. Candelas G, Jover JA, Fernandez B, RodriguezOlaverri JC, Calatayud J. Perforation of the sigmoid colon in a rheumatoid arthritis patient treated with methylprednisolone pulses. Scand J Rheumatol. 1998;27(2):152-3. doi: 10.1080/030097498441056

89. Venditti D, Valerio B, Ielpo B, Buonomo O, Petrella G. Bowel perforations in a patient affected by ChurgStrauss syndrome under high-dose steroid treatment: will alternative drugs reduce risk of surgery? Rheumatol Int. 2011 Sep;31(9):1239-41. doi: 10.1007/s00296-009-1289-5

90. Ruppert M, De Clerck L, van Offel J, Hubens G, Balliu $\mathrm{L}$, Vaneerdeweg W. Intestinal necrosis in a patient with rheumatoid arthritis receiving anti-TNF treatment. Acta Chir Belg. 2006 Mar-Apr;106(2):225-7. doi: 10.1080/00015458.2006.11679877 